\title{
Colour of sputum is a marker for bacterial colonisation in chronic obstructive pulmonary disease
}

\author{
Marc Miravitlles¹, Alicia Marín², Eduard Monsó3, Sara Vilà1, Cristian de la Roza4, Ramona Hervás³, Cristina Esquinas¹, \\ Marian García ${ }^{3}$, Laura Millares ${ }^{3}$, Josep Morera ${ }^{3}$ and Antoni Torres ${ }^{5}$
}

\begin{abstract}
Background: Bacterial colonisation in chronic obstructive pulmonary disease (COPD) contributes to airway inflammation and modulates exacerbations. We assessed risk factors for bacterial colonisation in COPD.

Methods: Patients with stable COPD consecutively recruited over 1 year gave consent to provide a sputum sample for microbiologic analysis. Bronchial colonisation by potentially pathogenic microorganisms (PPMs) was defined as the isolation of PPMs at concentrations of $\geq 10^{2}$ colony-forming units (CFU)/mL on quantitative bacterial culture. Colonised patients were divided into high $\left(>10^{5} \mathrm{CFU} / \mathrm{mL}\right)$ or low $\left(<10^{5} \mathrm{CFU} / \mathrm{mL}\right)$ bacterial load.

Results: A total of 119 patients ( $92.5 \%$ men, mean age 68 years, mean forced expiratory volume in one second [FEV $\left.{ }_{1}\right]$ [\% predicted] 46.4\%) were evaluated. Bacterial colonisation was demonstrated in 58 (48.7\%) patients. Patients with and without bacterial colonisation showed significant differences in smoking history, cough, dyspnoea, COPD exacerbations and hospitalisations in the previous year, and sputum colour. Thirty-six patients (62\% of those colonised) had a high bacterial load. More than $80 \%$ of the sputum samples with a dark yellow or greenish colour yielded PPMs in culture. In contrast, only $5.9 \%$ of white and $44.7 \%$ of light yellow sputum samples were positive $(P<0.001)$. Multivariate analysis showed an increased degree of dyspnoea (odds ratio $[\mathrm{OR}]=2.63,95 \%$ confidence interval $[\mathrm{Cl}] 1.53-5.09, P=$ $0.004)$ and a darker sputum colour $(\mathrm{OR}=4.11,95 \% \mathrm{Cl} 2.30-7.29, P<0.001)$ as factors associated with the presence of PPMs in sputum.

Conclusions: Almost half of our population of ambulatory moderate to very severe COPD patients were colonised with PPMs. Patients colonised present more severe dyspnoea, and a darker colour of sputum allows identification of individuals more likely to be colonised.
\end{abstract}

\section{Background}

Exacerbations are the main cost driver in chronic obstructive pulmonary disease (COPD), have a negative impact on the clinical course of the patients and are associated with increased mortality [1-3]. Around 70\% of exacerbations are infectious in nature, either bacterial, viral or mixed [4-7]. It has been shown that airway bacterial load in the stable state contributes to airway inflammation and modulates the character and frequency of exacerbations $[8,9]$. There is also evidence that bronchial

\footnotetext{
* Correspondence: marcm@separ.es

1 Fundació Clínic. Institut D'Investigacions Biomèdiques August Pi i Sunyer (IDIBAPS). Ciber de Enfermedades Respiratorias (CIBERES), Barcelona, Spain Full list of author information is available at the end of the article
}

colonisation influences the decline in lung function over time [10]. Different studies in which respiratory samples were obtained by the protected specimen brush (PSB) technique have shown a high prevalence of bronchial colonisation in COPD patients $[5,11,12]$. However, the practice of bronchoscopy to assess bronchial colonisation in routine clinical practice is not feasible and data that support the use of sputum samples to identify patients colonised by potentially pathogenic microorganisms (PPMs) are required.

Consequently, a cross-sectional study was designed to assess the frequency of bronchial bacterial colonisation using sputum samples and to identify risk factors for colonisation in stable ambulatory patients with COPD. The 
clinical characteristics of patients colonised and non-colonised with PPMs were compared as were those of patients with low and high bacterial loads in sputum samples.

\section{Methods}

A cross-sectional study was carried out to assess clinical characteristics associated with bronchial colonisation in stable ambulatory COPD patients. These patients were visited at the outpatient respiratory clinics of two acutecare tertiary hospitals in Barcelona, Spain and were consecutively recruited over one year. After completing the collection of data for this study, patients with bronchial colonisation were included in a randomised trial of antibiotic treatment the results of which have been reported elsewhere [13]. The protocol was approved by the institutional review board and all patients gave written informed consent.

\section{Study population}

Eligible patients were adults over 40 years of age, smokers or ex-smokers of at least 10 pack-years, with stable COPD, defined as a post-bronchodilator forced expiratory volume in one second $\left(\mathrm{FEV}_{1}\right) /$ forced vital capacity (FVC) ratio of $<70 \%$. A $\mathrm{FEV}_{1}$ of $<60 \%$ of the predicted value higher than 0.70 litres and a negative bronchodilator test (increase in $\mathrm{FEV}_{1}<200 \mathrm{~mL}$ and $<12 \%$ of baseline) was required for inclusion in the study as was a history of at least one documented exacerbation in the previous year. Clinical stability was defined by the attending physician on clinical grounds based on the absence of symptoms of exacerbation and use of any oral or systemic antibiotics or a course of oral corticosteroids in the 6 weeks prior to inclusion.

The exclusion criteria were the following: (1) previous diagnosis of bronchial asthma, bronchiectasis demonstrated by a chest X-ray or computed tomography (CT) scan, or other relevant pulmonary diseases apart from COPD; (2) chronic treatment with oral corticosteroids at any dose; (3) formal contraindication for sputum induction or impossibility to obtain a valid sputum sample for analysis; and (4) participation in another clinical study concurrently or within the previous 3 months.

\section{Study procedures}

At the time of inclusion in the study, the investigator verified that the patient met the eligibility criteria and details of medical history were recorded. Information regarding comorbidities, particularly cardiovascular diseases, diabetes and liver or renal failure was collected. A forced spirometry was performed following criteria of the Spanish Society of Pneumology and Thoracic Surgery [14] and sputum samples were obtained. Patients unable to produce sputum were susceptible to reassessment for airway colonisation at least one month after the initial investigation for a maximum of three consecutive visits.

\section{Microbiological sputum study}

A sputum sample was obtained and processed within 60 minutes on the day of the visit according to standard methods $[13,15,16]$. Patients who did not produce sputum spontaneously underwent sputum induction. In brief, patients were pretreated with an inhaled $\beta_{2}$-agonist ten minutes before the nebulisation of isotonic saline (0.9\%) with an ultrasonic nebuliser (Ultraneb2000, DeVilbiss Healthcare Inc., Somerset, PA, USA), that was followed by increasing concentrations of hypertonic saline (3\%, $4 \%$ and 5\%), for $7 \mathrm{~min}$ with each concentration. After every induction, the patient attempted to obtain a sputum sample by coughing, and the nebulisation procedure was stopped when the sputum volume collected was 1 $\mathrm{mL}$ or more [17]. In current smokers, sputum induction was performed after at least 6 hours of tobacco abstinence. The purulence of sputum was graded in a scale from 1 to 5 according to the colour from white -1 - to greenish -5-, always by the same researcher at each centre. The sample was weighed and processed with a 4-fold volume of dithiothreitol (Sputasol, Oxoid Ltd., Hants, UK) and was cultured. Sputum samples were serially diluted and plated on chocolate agar enriched, chocolate agar with bacitracin, Haemophilus-selective agar, blood agar, and McConkey agar. Plates were incubated for 24-48 hours at $37^{\circ} \mathrm{C}$ and in $5 \% \mathrm{CO}_{2}$ atmosphere. Microorganisms were identified by colony morphology, Gram staining and specific culture conditions (e.g., requirements for factors for growth, presence of oxidase and catalase, porphyrin synthesis). Cultures were considered positive for bronchial colonisation if microorganisms considered as PPMs such as Haemophilus influenzae, Haemophilus parainfluenzae, Streptococcus pneumoniae, Moraxella catarrhalis, Pseudomonas aeruginosa, enterobacteria and/or Staphylococcus aureus were grown at loads of at least 100 colony-forming units (CFU)/mL according to previously defined criteria $[18,19]$. Colonised patients were then divided into high $\left(>10^{5} \mathrm{CFU} / \mathrm{mL}\right)$ or low $\left(\leq 10^{5}\right.$ $\mathrm{CFU} / \mathrm{mL}$ ) bacterial load according to previous studies $[4,8]$.

Sputum concentrations of pro-inflammatory cytokines, including interleukin-1 (IL-1), interleukin-6 (IL-6), interleukin-8 (IL-8), and tumour necrosis factor-alpha (TNFalpha) were measured using quantitative sandwich immunoassay techniques in processed supernatants as previously described [20].

\section{Statistical analysis}

Variables were presented as mean values and standard deviations, those not following a normal distribution were presented as median and interquartile range (IQR, 
25th-75th percentile). Categorical variables were compared with the chi-square test and continuous variables with the Student's $t$ test or the Mann-Whitney U test when data departed from normality. Following univariate analysis, variables were included in two stepwise logistic regression models constructed as exploratory analysis to identify independent risk factors for bronchial colonisation and factors significantly associated with high bacterial load as opposed to low bacterial load and sterile sputum cultures. The variables included in the models were: age, gender, active versus ex-smoker, pack-years of smoking, $\mathrm{FEV}_{1}$ (\% predicted), degree of dyspnoea, colour of sputum, cardiovascular comorbidity and number of exacerbations and hospitalisations the previous year. Bilateral two-tailed hypotheses were formulated and 95\% confidence intervals (CI) were calculated. Statistical significance was set at $P<0.05$.

\section{Results}

A total of 119 patients $(92.5 \%$ men) with a mean (standard deviation, SD) age of 68.1 (9.1) years were studied. The clinical characteristics of these patients are reported in Table 1. Induction of sputum was necessary to obtain a valid sputum sample in only 5 cases ( 3 in one centre and 2 in the other). Bacterial colonisation was demonstrated in $58(48.7 \%)$ patients, 2 in samples obtained by sputum induction. Results of sputum microbiology are shown in Table 2. Colonisation by a single PPM was recorded in 50 patients. Eight subjects yielded more than one PPM in

\section{Table 1: Clinical characteristics of the study population}

\begin{tabular}{lc}
\hline Data & Frequency \\
\hline Subjects, no. & 119 \\
Sex, men, no. (\%) & $112(92.5)$ \\
Age, years, mean (SD) & $68.1(9.1)$ \\
Current smokers, no. (\%) & $11(9.2)$ \\
Smoking, pack-years, & $40(21.1)$ \\
mean (SD) & \\
Cardiovascular morbidity, & $36(29.7)$ \\
no. (\%) & $1.3(0.5)$ \\
Exacerbations in the previous & \\
year, mean (SD) & $0.3(0.5)$ \\
$\quad$ Requiring hospital & \\
$\quad$ admission & \\
Post-bronchodilator & \\
spirometry, mean (SD) & \\
FVC, mL & \\
FVC, \% & $68.9(19.2)$ \\
FEV ${ }_{1}$, mL & $1406(493)$ \\
FEV ${ }_{1}, \%$ & $46.4(14.1)$ \\
\hline
\end{tabular}

Table 2: Potentially Pathogenic Microorganisms (PPMs) isolated in colonised COPD patients.

\begin{tabular}{|c|c|}
\hline & No. (\%) \\
\hline \multicolumn{2}{|l|}{ Microorganisms isolated } \\
\hline Haemophilus influenzae & $21(42)$ \\
\hline $\begin{array}{l}\text { Haemophilus } \\
\text { parainfluenzae }\end{array}$ & $15(30)$ \\
\hline $\begin{array}{l}\text { Pseudomonas } \\
\text { aeruginosa }\end{array}$ & $5(10)$ \\
\hline $\begin{array}{l}\text { Streptococcus } \\
\text { pneumoniae }\end{array}$ & $4(8)$ \\
\hline Moraxella catarrhalis & $4(8)$ \\
\hline Staphylococcus aureus & $1(2)$ \\
\hline \multicolumn{2}{|l|}{$\begin{array}{l}\text { Mixed colonisations (from } \\
\text { the above microorganisms) }\end{array}$} \\
\hline $\begin{array}{l}\text { H. influenzae }+S . \\
\text { pneumoniae }\end{array}$ & 1 \\
\hline $\begin{array}{l}\text { H. influenzae }+P \text {. } \\
\text { aeruginosa }\end{array}$ & 3 \\
\hline $\begin{array}{l}H . \text { influenzae }+H \text {. } \\
\text { parainfluenzae }\end{array}$ & 2 \\
\hline $\begin{array}{l}\text { P. aeruginosa }+S \text {. } \\
\text { viridans }\end{array}$ & 2 \\
\hline
\end{tabular}

their sputum. Haemophilus influenzae and H. parainfluenzae made up $72 \%$ of all bacterial isolates.

There were significant differences in cigarette consumption, cough, dyspnoea, comorbidities, COPD exacerbations and hospitalisations in the previous year, and sputum colour between patients with and without bacterial colonisation (Table 3).

The distribution of colonised patients according to sputum colour is presented in Figure 1. Samples with colour 1 (white) were predominantly sterile, whereas in the samples with colours 3 to 5 (yellow to greenish) the prevalence of colonisation was higher than $80 \%$. Colour number two (light yellow) was not discriminative between colonised and non-colonised.

When colonised patients were divided according to bacterial load, 36 patients had a high bacterial load $\left(>10^{5}\right.$ $\mathrm{CFU} / \mathrm{mL}$ ) and the remaining 22 had a low bacterial load $\left(\leq 10^{5} \mathrm{CFU} / \mathrm{mL}\right)$. The characteristics of colonised patients with a high bacterial load $(\mathrm{n}=36)$ were compared with a group formed by non-colonised patients $(\mathrm{n}=61)$ and those with a low bacterial load $(\mathrm{n}=22)$ considered together $(n=83)$. Statistically significant differences between the two groups in smoking (pack-years), cough, grade of dyspnoea, hospitalisations in the previous year and sputum colour persisted when patients with high bacterial loads were compared with the remaining 
Table 3: Differences between stable COPD patients with and without bacterial colonisation

\begin{tabular}{|c|c|c|c|}
\hline Variables & Colonised $(n=58)$ & Not colonised $(n=61)$ & $P$ value \\
\hline Sex, men, no. (\%) & $54(93.1)$ & $55(90.2)$ & 0.74 \\
\hline Age, years, mean (SD) & $68.3(8.3)$ & $67.6(9.8)$ & 0.67 \\
\hline Current smokers, no. (\%) & $7(12.1)$ & $4(6.6)$ & 0.35 \\
\hline Smoking, pack-years, mean (SD) & $46.7(25.1)$ & $34.2(23.4)$ & 0.006 \\
\hline Cardiovascular morbidity, no. (\%) & $22(37.9)$ & $20(32.8)$ & 0.23 \\
\hline Comorbid conditions, mean (SD) & $1.06(0.99)$ & $0.61(1.02)$ & 0.025 \\
\hline Use of inhaled steroids, no. (\%) & $46(79.3)$ & $47(77.1)$ & 0.83 \\
\hline \multicolumn{4}{|l|}{ Symptoms, no. (\%) } \\
\hline Dyspnoea & $56(96.5)$ & $58(95.1)$ & 0.72 \\
\hline Cough & $44(75.9)$ & $56(91.8)$ & 0.024 \\
\hline Expectoration & $57(98.3)$ & $58(95.1)$ & 0.62 \\
\hline Grade of dyspnoea, mean (SD) & $1.78(0.92)$ & $1.15(0.54)$ & $<0.001$ \\
\hline \multicolumn{4}{|c|}{ Exacerbations in the previous year, no. (\%) } \\
\hline Number & & & 0.021 \\
\hline$\leq 2$ & $31(53.4)$ & $47(77.1)$ & \\
\hline$>2$ & $27(46.6)$ & $14(22.9)$ & \\
\hline Requiring hospital admission & & & 0.007 \\
\hline None & $36(62.1)$ & $51(83.6)$ & \\
\hline$\leq 1$ & $16(27.6)$ & $10(16.4)$ & \\
\hline$>1$ & $6(10.3)$ & 0 & \\
\hline \multicolumn{4}{|l|}{ Lung function tests, mean (SD) } \\
\hline $\mathrm{FVC}, \mathrm{mL}$ & $2852.7(979.1)$ & $2710.9(911.5)$ & 0.41 \\
\hline FVC, \% & $70.5(19.5)$ & $66.7(18.9)$ & 0.28 \\
\hline $\mathrm{FEV}_{1}, \mathrm{~mL}$ & $1411.4(511.7)$ & $1380.0(433.1)$ & 0.72 \\
\hline $\mathrm{FEV}_{1}, \%$ & $47.4(15.2)$ & $45.1(13.1)$ & 0.38 \\
\hline $\mathrm{FEV}_{1} / \mathrm{FVC}$ & $50.4(11.8)$ & $52.6(13.9)$ & 0.43 \\
\hline \multicolumn{4}{|l|}{ Sputum analysis } \\
\hline Colour, mean (SD) & $2.94(1.0)$ & $1.56(0.8)$ & $<0.001$ \\
\hline \multicolumn{4}{|c|}{$\begin{array}{l}\text { Pro-inflammatory cytokines, median } \\
\text { (IQR) in } \mathrm{pg} / \mathrm{mL}\end{array}$} \\
\hline $\mathrm{IL}-1, \mathrm{n}=53$ & $14(4-432)$ & $168(49-758)$ & 0.82 \\
\hline $\mathrm{IL}-6, \mathrm{n}=53$ & $258(76-653)$ & $112(33-368)$ & 0.62 \\
\hline IL-8, n = 61 & $13480(1335-43400)$ & $5390(252-14335)$ & 0.27 \\
\hline TNF-alpha, $\mathrm{n}=54$ & $45(20-94)$ & $35(10-183)$ & 0.12 \\
\hline
\end{tabular}

$\mathrm{FVC}=$ forced vital capacity; $\mathrm{FEV}_{1}$ = forced expiratory volume in the first second; IQR = interquartile range; IL= interleukin; $\mathrm{TNF}=$ tumour necrosis factor.

patients (Table 4). Sufficient sputum for inflammatory analysis was available from only 61 subjects, all from spontaneous sputum. Sputum concentrations of inflammatory markers showed a great inter-individual variability and did not follow a normal distribution. There were no significant differences in sputum concentrations for any of the inflammatory markers analysed between patients with or without bacterial colonisation (Table 3). The lack of significance persisted when patients with high bacterial load were compared with those with low bacterial load and not colonised. However, in this last comparison, patients with high bacterial load presented consistently (but not significantly) higher concentrations of all pro-inflammatory cytokines except IL-6 (Table 4). 


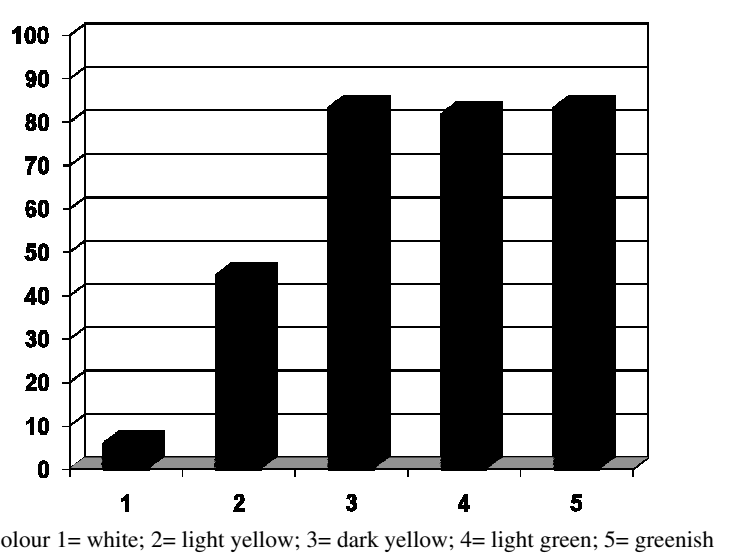

Figure 1 Percentage of bacterial colonisation according to sputum colour (differences statistically significant at $P<0.001$ ).

The results of the multivariate analysis were very similar when identifying the factors significantly associated with the presence of PPMs or on classifying the population according to bacterial load. In both cases, only the degree of dyspnoea and sputum colour were significantly and independently associated with the presence of PPMs and with high bacterial load. Sputum colour was a stronger indicator of the presence of positive cultures for PPMs than its load (Table 5).

\section{Discussion}

In the present study, bacterial colonisation of the airways by PPMs, mainly $H$. influenzae and $H$. parainfluenzae, was reported in $49 \%$ of patients with stable COPD. This finding adds evidence to a high prevalence of bacterial colonisation of airways in stable COPD reported by others [4,5,9-12]. Interestingly, our results using sputum samples are quite similar to those obtained in other studies with the use of the PSB technique or bronchial lavage for microbiologic assessment of the lower airways in COPD $[4,5,11,12,20,21]$. The possibility of sputum collection along a maximum of three monthly clinical visits and the use of the induced sputum technique in selected cases may have accounted for this high diagnostic yield of the sputum. However, most of our patients were able to produce a valid sputum sample for microbiological examination and induction of sputum was necessary in only 5 cases. A previous study by our group demonstrated that spontaneous and induced sputum yielded equivalent results in terms of frequency of bacterial colonisation and species recovered [22]. A pooled analysis of data from studies that used PSB demonstrated that a PPM load $\geq 10^{2}$ $\mathrm{CFU} / \mathrm{mL}$ should be considered abnormal and allowed the estimation that at least one quarter of the patients with stable COPD were colonised by PPMs [5]. Furthermore, most patients with exacerbated COPD had concentration of PPMs $>10^{5}[4,5]$. Since there is no universally accepted cut-off for high bacterial load in sputum samples, a $10^{5}$ $\mathrm{CFU} / \mathrm{mL}$ concentration was used in our study $[4,8]$. With this value, $30 \%$ of our total population and almost two thirds of the colonised patients in our study had a high PPM load.

Bacterial colonisation in our study was related to cumulative consumption of cigarette smoking, history of exacerbations in the previous year and sputum colour. Exacerbations in the previous year leading to hospitalisation were associated with increased bacterial load, although this relationship disappeared on multivariate analysis. In other studies, current smoking and severe airflow obstruction have been identified as predisposing factors for bacterial colonisation in stable COPD $[11,12]$. However, we did not observe significant differences in lung function between colonised and non-colonised patients. The relationship between lung function and frequency of colonisation is not clear, since a lack of association between $\mathrm{FEV}_{1}$ and colonisation has also been observed in other studies $[8,12,21,23]$ and may be due, at least in part, to the under-representation of mild patients in most series as well as in the current study. Interestingly, the only two factors identified in multivariate analysis to be significantly and independently associated with both presence of bacterial colonisation and high bacterial load were a more severe degree of dyspnoea and a darker colour of sputum. The degree of dyspnoea is a marker of severity of COPD and being a categorical variable with a wider distribution in our population probably contributed to its demonstrated association with colonisation, in contrast to the severity of $\mathrm{FEV}_{1}$ impairment.

Regarding bronchial inflammation, it should be noted that we did not find increased sputum concentrations of pro-inflammatory cytokines in patients with bacterial colonisation. Different reasons may explain this finding, including a small number of patients with valid samples for analysis, the inter-individual variability in the sputum concentrations of the cytokines was very large [24], and there was a large number of patients with low bacterial loads. In fact, Hill et al. [8] have demonstrated that markers of inflammation increased progressively with increasing bacterial load in patients with stable COPD. Consequently, when our colonised patients were categorized according to high or low bacterial load, besides the persistence of the clinical differences already observed between the colonised and non-colonised groups (i.e., cigarette smoking, hospitalisations in the previous year, grade of dyspnoea and sputum colour) a non-significant trend towards higher sputum concentrations of inflammatory markers (except IL-6) was observed in patients with high bacterial load. Our results concur with previous observations regarding the lack of association 
Table 4: Differences between colonised and non-colonised COPD patients according to bacterial load

\begin{tabular}{|c|c|c|c|}
\hline Variables & $\begin{array}{l}\text { High bacterial load }\left(\geq 10^{5}\right) \\
\qquad(n=36)\end{array}$ & $\begin{array}{l}\text { Low bacterial load }\left(<10^{5}\right) \\
\text { and not colonised }(n=83)\end{array}$ & $P$ value \\
\hline Sex, men, no. (\%) & $33(91.7)$ & $76(91.6)$ & 0.98 \\
\hline Age, years, mean (SD) & $68.6(6.9)$ & $67.7(9.9)$ & 0.63 \\
\hline Current smokers, no. (\%) & $6(16.7)$ & $5(6)$ & 0.086 \\
\hline $\begin{array}{l}\text { Smoking, pack-years, } \\
\text { mean (SD) }\end{array}$ & $48.5(22.5)$ & $36.7(25.2)$ & 0.017 \\
\hline $\begin{array}{l}\text { Cardiovascular morbidity, } \\
\text { no. (\%) }\end{array}$ & $11(30.6)$ & $31(37.3)$ & 0.34 \\
\hline $\begin{array}{l}\text { Comorbid conditions, } \\
\text { mean (SD) }\end{array}$ & $0.86(0.99)$ & $0.83(1.02)$ & 0.88 \\
\hline Use of inhaled steroids, no (\%) & $29(80.6)$ & $64(77.1)$ & 0.81 \\
\hline \multicolumn{4}{|l|}{ Symptoms, no. (\%) } \\
\hline Dyspnoea & $36(100)$ & 78 (93.9) & 0.66 \\
\hline Cough & $25(69.4)$ & $75(90.4)$ & 0.007 \\
\hline Expectoration & $36(100)$ & $79(95.2)$ & 0.31 \\
\hline Grade of dyspnoea, mean (SD) & $1.86(0.83)$ & $1.28(0.73)$ & $<0.001$ \\
\hline \multicolumn{4}{|l|}{$\begin{array}{l}\text { Exacerbations in the } \\
\text { previous year, no. (\%) }\end{array}$} \\
\hline Number & & & 0.32 \\
\hline$\leq 2$ & $20(55.6)$ & $58(69.9)$ & \\
\hline$>2$ & $16(44.4)$ & $25(30.1)$ & \\
\hline $\begin{array}{l}\text { Requiring hospital } \\
\text { admission }\end{array}$ & & & 0.003 \\
\hline None & $20(55.6)$ & $67(80.7)$ & \\
\hline$\leq 1$ & $11(30.6)$ & $15(18.1)$ & \\
\hline$>1$ & $5(13.9)$ & $1(1.2)$ & \\
\hline \multicolumn{4}{|l|}{$\begin{array}{l}\text { Lung function tests, mean } \\
\text { (SD) }\end{array}$} \\
\hline $\mathrm{FVC}, \mathrm{mL}$ & $2936.9(975.7)$ & $2712(927.6)$ & 0.23 \\
\hline FVC, \% & $71.9(21.0)$ & $67.1(18.4)$ & 0.21 \\
\hline $\mathrm{FEV}_{1}, \mathrm{~mL}$ & $1423.9(536.5)$ & $1382(443.1)$ & 0.66 \\
\hline $\mathrm{FEV}_{1}, \%$ & $47.3(15.9)$ & $45.8(13.4)$ & 0.61 \\
\hline $\mathrm{FEV}_{1} / \mathrm{FVC}$ & $48.9(11.2)$ & $52.7(13.5)$ & 0.15 \\
\hline \multicolumn{4}{|l|}{ Sputum analysis } \\
\hline Colour, mean (SD) & $2.97(0.94)$ & $2.01(1.08)$ & $<0.001$ \\
\hline \multicolumn{4}{|l|}{$\begin{array}{l}\text { Pro-inflammatory } \\
\text { cytokines, median (IQR) } \\
\text { in } \mathrm{pg} / \mathrm{mL}\end{array}$} \\
\hline $\mathrm{IL}-1, \mathrm{n}=53$ & $47(5-593)$ & $29(4-255)$ & 0.14 \\
\hline $\mathrm{IL}-6, \mathrm{n}=53$ & $134(39-381)$ & $169(34-415)$ & 0.18 \\
\hline $\mathrm{IL}-8, \mathrm{n}=61$ & $8060(460-31400)$ & $4890(201-15025)$ & 0.09 \\
\hline TNF-alpha, $n=54$ & $76(11-269)$ & $38(11-71)$ & 0.96 \\
\hline
\end{tabular}

$\mathrm{FVC}=$ forced vital capacity; $\mathrm{FEV}_{1}=$ forced expiratory volume in the first second; IQR = interquartile range; IL= interleukin; $\mathrm{TNF}=$ tumour necrosis factor. 
Table 5: Results of multivariate analysis of factors associated with presence of bacteria in sputum and with high bacterial load.

\begin{tabular}{lccc}
\hline Factor & OR & $\mathbf{9 5 \% ~ C l}$ & P value \\
& & \\
\hline \multicolumn{2}{l}{ Factors associated with bacteria in sputum } & $1.53-5.09$ & 0.004 \\
Degree of dyspnoea & 2.63 & $2.30-7.29$ & $<0.001$ \\
Sputum colour & 4.11 & $1.17-3.46$ & 0.012 \\
Factors associated with high bacterial load as opposed to no bacteria and low bacterial load & 0.001 \\
Degree of dyspnoea & 2.01 & $1.32-2.99$ & \\
Sputum colour & 1.99 & & \\
\hline
\end{tabular}

between colonisation and increased IL-6 [9,10] but are discordant with other works showing significantly increased bronchial IL-8 and TNF-alpha in colonised patients, particularly with H.influenzae [9,10,21,23,25]. Therefore, our data, if confirmed in a larger sample of patients, would also suggest a dose-response relationship between bacterial load and bronchial inflammation and that a threshold of bacterial load might be necessary to elicit a significant inflammatory reaction in the airways $[5,6,26]$. In contrast, Sehti et al. [27] examined whether the increase in bacterial concentrations functions as a separate mechanism of exacerbation induction, independent of a new strain acquisition. In a prospective longitudinal cohort of COPD patients assessed during exacerbations and stable disease, sputum concentrations of pre-existing strains of $H$. influenzae and $H$. haemolyticus were not significantly different in exacerbation versus stable disease. Concentrations of $M$. catarrhalis and $S$. pneumoniae were even lower during exacerbations compared with stable periods. However, concentrations of new strains of $H$. influenzae and $M$. catarrhalis were increased during exacerbations, but the differences were small. These authors speculate that change in bacterial load was unlikely to be a major primary mechanism of exacerbation induction in COPD $[27,28]$. This hypothesis is a matter of debate, because the interpretation of what a significant increase in bacterial load is when measured in a logarithmic scale is not clear [10], and when transformed to a non-logarithmic scale, the differences in absolute bacterial counts were of a very high magnitude [29].

The identification of bronchial colonisation has clinical implications. Patel et al. [9] demonstrated that the presence of lower airway bacterial colonisation in stable COPD was significantly related to exacerbation frequency and severity. In the study of Rosell et al. [5], again high bacterial loads were associated with exacerbation and showed a statistically significant dose-response relationship between bacterial load and exacerbation after adjustment for covariates. In our study colonised patients had significantly more exacerbations and hospital admis- sions the year previous to the study compared with noncolonised patients, but the significance disappeared on multivariate analysis. It should be taken into account that our study was neither designed nor powered to demonstrate differences in exacerbation or hospitalisation rates between colonised and non-colonised COPD patients. Therefore, the identification of patients colonised by PPMs using a non-invasive and relatively inexpensive technique such as the analysis of sputum may play an important role in the management of severe and very severe COPD, particularly if intervention studies with antibiotics demonstrate improved clinical outcomes [13].

To facilitate the diagnosis of bronchial colonisation the use of a surrogate marker could be of interest. Purulence (colour) of sputum graded by the investigator with a simple scale from 1 to 5 revealed significant differences in colour between colonised and non-colonised patients. Patients with colour 3 or higher (dark yellow to green sputum) had a prevalence of bacterial colonisation greater than $80 \%$. The relevance of sputum colour has been already described and validated for exacerbated patients in which yellowish or greenish sputum is significantly associated with a bacterial exacerbation compared with white (non-bacterial) sputum [30,31] but the relationship between sputum colour and bacterial colonisation in stable COPD has deserved little attention [8].

The present results should be interpreted taking into account some limitations of the study, particularly the small sample size may not have allowed determination of sputum concentrations of inflammatory markers in all samples, in most cases due to the small recovery of sputum that did not provide enough supernatant for the quantification of inflammatory mediators. The cross-sectional design did not allow the dynamics and time course of bacterial colonisation and airway inflammation during exacerbations to be examined. Patients with negative bronchodilator test were included to exclude individuals with asthma who are less likely to be colonised, but the results may not be extrapolated to partially reversible COPD patients. High concentrations of PPMs in sputum samples, however, is a simple parameter that may help to 
select candidates to participate in antibiotic trials of stable COPD in order to demonstrate bacterial eradication and potentially prolong time to exacerbation $[6,32,33]$.

\section{Conclusions}

Almost half of a population of ambulatory moderate to very severe COPD patients carry PPMs in their airways. Colonised patients had more severe dyspnoea, and sputum colour allows the identification of patients most likely to be colonised by PPMs.

\section{List of abbreviations}

CFU: colony-forming units; CI: confidence interval; COPD: Chronic obstructive pulmonary disease; CT: computed tomography; $\mathrm{FEV}_{1}$ : forced expiratory volume in one second; FVC: forced vital capacity; IQR: interquartile range; IL-1: interleukin-1; IL-6: interleukin-6; IL8: interleukin-8; OR: odds ratio; PPMs: potentially pathogenic microorganisms; PSB: protected specimen brush; SD: standard deviation; TNF-alpha: tumour necrosis factor-alpha.

\section{Competing interests}

Marc Miravitlles has received honoraria for consultancy and speaking at scientific meetings from Bayer Schering, GlaxoSmithKline, Boehringer Ingelheim and AstraZeneca. Cristian de la Roza is fully employed in the Medical Department of Bayer Schering Pharma. Antoni Torres has received honoraria for consultancy and speaking at scientific meetings from Bayer and Covidien. Alicia Marín, Eduard Monsó, Sara Vilà, Ramona Hervás, Cristina Esquinas, Marian García, Laura Millares and Josep Morera have no conflict of interest to disclose.

\section{Authors' contributions}

MM designed the study, participated in the analysis and interpretation of data and wrote the manuscript. EM, JM and AT designed the study, and participated in the analysis and interpretation of data. AM and SV recruited the patients, collected data and participate in the design and analysis. CR participated in the design and analysis of the study. $\mathrm{CE}$ and $\mathrm{RH}$ collected and processed the samples, and created and cleaned the database. LM and MG perfomed the microbiological investigations. All authors read and approved the final manuscript.

\section{Acknowledgements}

This study was funded by unrestricted grants from Fundación Respira-SEPAR and La Marató de TV3 and Bayer Schering Pharma. We thank Marta Pulido, MD, for providing an outline for this manuscript and support in editing and journal styling. Bayer Schering Pharma was the source of funding for medical writing. The funding bodies had no role in study design, data analysis, interpretation and writing of the manuscript, and in the decision to submit the manuscript for publication.

\section{Author Details}

'Fundació Clínic. Institut D'Investigacions Biomèdiques August Pi i Sunyer (IDIBAPS). Ciber de Enfermedades Respiratorias (CIBERES), Barcelona, Spain, 2Department of Pneumology, Hospital Germans Trias i Pujol. Autonomous University of Barcelona; Ciber de Enfermedades Respiratorias (CIBERES), Barcelona, Spain, ${ }^{3}$ Department of Pneumology, Hospital Germans Trias i Pujol, Ciber de Enfermedades Respiratorias (CIBERES), Badalona, Barcelona, Spain, ${ }^{4}$ Medical Department, Bayer Schering Pharma, Sant Joan Despi, Barcelona, Spain and 5 Department of Pneumology, Institut Clínic del Tòrax (IDIBAPS), Hospital Clínic, Ciber de Enfermedades Respiratorias (CIBERES), Barcelona, Spain

Received: 8 January 2010 Accepted: 14 May 2010

Published: 14 May 2010

\section{References}

1. Miravitlles M, Murio C, Guerrero T, Gisbert R: Pharmacoeconomic evaluation of acute exacerbations of chronic bronchitis and COPD. Chest 2002, 121:1449-1455.

2. Donaldson GC, Seemungal TA, Bhowmik A, Wedzicha JA: Relationship between exacerbation frequency and lung function decline in chronic obstructive pulmonary disease. Thorax 2002, 57:847-852.

3. Soler-Cataluña JJ, Martínez-García MA, Román P Sánchez, Salcedo E, Navarro M, Ochando R: Severe acute exacerbations and mortality in patients with chronic obstructive pulmonary disease. Thorax 2005, 60:925-931.

4. Monsó E, Ruiz J, Rosell A, Manterola J, Fiz J, Morera J, Ausina V: Bacterial infection in chronic obstructive pulmonary disease. A study of stable and exacerbated outpatients using the protected specimen brush. Am J Respir Crit Care Med 1995, 152:1316-1320.

5. Rosell A, Monsó E, Soler N, Torres F, Angrill J, Riise G, Zalacaín R, Morera J, Torres A: Microbiologic determinants of exacerbation in chronic obstructive pulmonary disease. Arch Intern Med 2005, 165:891-897.

6. Miravitlles M: Exacerbations of chronic obstructive pulmonary disease: when are bacteria important? Eur Respir J 2002, 20(Suppl 36):1s-11s.

7. Papi A, Bellettato CM, Braccioni F, Romagnoli M, Casolari P, Caramori G, Fabbri LM, Johnston SL: Infections and airway inflammation in chronic obstructive pulmonary disease severe exacerbations. Am J Respir Crit Care Med 2006, 173:1114-1121.

8. Hill AT, Campbell EJ, Hill SL, Bayley DL, Stockley RA: Association between airway bacterial load and markers of airway inflammation in patients with stable chronic bronchitis. Am J Med 2000, 109:288-295.

9. Patel IS, Seemungal TA, Wilks M, Lloyd-Owen SJ, Wedzicha JA: Relationship between bacterial colonisation and the frequency, character, and severity of COPD exacerbations. Thorax 2002, 57:759-764.

10. Wilkinson TM, Patel IS, Wilks M, Donaldson GC, Wedzicha JA: Airway bacterial load and FEV1 decline in patients with chronic obstructive pulmonary disease. Am J Respir Crit Care Med 2003, 167:1090-1095.

11. Zalacain R, Sobradillo V, Amilibia J, Barrón J, Achótegui V, Pijoan Jl, Llorente JL: Predisposing factors to bacterial colonisation in chronic obstructive pulmonary disease. Eur Respir J 1999, 13:343-348.

12. Monsó E, Rosell A, Bonet G, Manterola J, Cardona PJ, Ruiz J, Morera J: Risk factors for lower airway bacterial colonisation in chronic bronchitis. Eur Respir J 1999, 13:338-342.

13. Miravitlles M, Marín A, Monsó E, Vilà S, de la Roza C, Hervás R, Esquinas C, García M, Millares L, Morera J, Torres A: Efficacy of moxifloxacin in the treatment of bronchial colonisation in COPD. Eur Respir J 2009, 34:1066-1071.

14. Sanchis J y Grupo de trabajo de la SEPAR: Normativa para la práctica de la espirometría forzada. Arch Bronconeumol 1989, 25:132-142.

15. Pin I, Gibson PG, Kolendowicz R, Girgis-Gabardo A, Denburg JA, Hargreave $\mathrm{FE}$, Dolovich J: Use induced sputum cell counts to investigate airway inflammation in asthma. Thorax 1992, 47:25-29.

16. Pizzichini E, Pizzichini MM, Efthimiadis A, Evans S, Morris MM, Squillace D Gleich GJ, Dolovich J, Hargreave FE: Indices of airway inflammation in induced sputum: reproducibility and validity of cell and fluid-phase measurements. Am J Respir Crit Care Med 1996, 154:308-317.

17. Aaron SD, Angel JB, Lunau M, Wright K, Fex C, Le Saux N, Dales RE: Granulocyte inflammatory markers and airway infection during acute exacerbation of chronic obstructive pulmonary disease. Am J Respir Crit Care Med 2001, 163:349-355

18. Angrill J, Agustí C, de Celis R, Rañó A, Gonzalez J, Solé T, Xaubet A Rodriguez-Roisin R, Torres A: Bacterial colonisation in patients with bronchiectasis: microbiological pattern and risk factors. Thorax 2002, 57:15-19.

19. Cabello H, Torres A, Celis R, El-Ebiary M, Puig de la Bellacasa J, Xaubet A, González J, Agustí C, Soler N: Bacterial colonisation of distal airways in healthy subjects and chronic lung disease: a bronchoscopic study. Eur Respir J 1997, 10:1137-1144.

20. Weinreich UM, Korsgaard J: Bacterial colonisation of lower airways in health and chronic lung disease. Clinical Respiratory Journal 2008, 2:116-122.

21. Soler N, Ewig S, Torres A, Filella X, Gonzalez J, Xaubet A: Airway inflammation and bronchial microbial patterns in patients with stable chronic obstructive pulmonary disease. Eur Respir J 1999, 14:1015-1022. 
22. Marin A, García M, Badorrey I, Sabrià M, Morera J, Monsó E: Spontaneous sputum production as a marker of bacterial colonisation in stable COPD. Eur Respir J 2005, 26(Suppl 49):232. abstract

23. Sethi S, Maloney J, Grove L, Wrona C, Berenson CS: Airway inflammation and bronchial bacterial colonisation in chronic obstructive pulmonary disease. Am J Respir Crit Care Med 2006, 173:991-998.

24. Sapey E, Bayley D, Ahmad A, Newbold P, Snell N, Stockley RA: Interrelationships between inflammatory markers in patients with stable COPD with bronchitis: intra-patient and inter-patient variability. Thorax 2008, 63:493-503.

25. Bresser P, Out TA, van Alphen L, Jansen HM, Lutter R: Airway inflammation in nonobstructive and obstructive chronic bronchitis with chronic Haemophilus influenzae airway infection. Comparison with noninfected patients with chronic obstructive pulmonary disease. Am J Respir Crit Care Med 2000, 162:947-952.

26. Bresser P, van Alphen L, Habets FJ, Hart AA, Dankert J, Jansen HM, Lutter R: Persisting Haemophilus influenzae strains induce lower levels of interleukin- 6 and interleukin-8 in H292 lung epithelial cells than nonpersisting strains. Eur Respir J 1997, 10:2319-2326.

27. Sethi S, Sethi R, Eschberger K, Lobbins P, Cai X, Grant BJ, Murphy TF: Airway bacterial concentration and exacerbations of chronic obstructive pulmonary disease. Am J Respir Crit Care Med 2007, 176:356-361.

28. Sethi S, Evans N, Grant BJ, Murphy TF: New strains of bacteria and exacerbations of chronic obstructive pulmonary disease. NEngl J Med 2002, 347:465-471.

29. Abusriwil H, Stockley RA: Bacterial load and exacerbations of COPD. Am J Respir Crit Care Med 2008, 177:1048-1049.

30. Stockley RA, O'Brien C, Pye A, Hill SL: Relationship of sputum colour to nature and outpatient management of acute exacerbations of COPD. Chest 2000, 117:1638-1645.

31. Soler N, Agustí C, Angrill J, Puig de la Bellacasa J, Torres A: Bronchoscopic validation of the significance of sputum purulence in severe exacerbations of chronic obstructive pulmonary disease. Thorax 2006, 62:29-35.

32. Wilson R: Using antibiotics to delay exacerbations of chronic obstructive pulmonary disease. Hot Topics Respir Dis 2006, 2:21-26.

33. Chodosh S: Clinical significance of the infection-free interval in the management of acute bacterial exacerbations of chronic bronchitis. Chest 2005, 127:2231-226.

doi: $10.1186 / 1465-9921-11-58$

Cite this article as: Miravitlles et al., Colour of sputum is a marker for bacterial colonisation in chronic obstructive pulmonary disease Respiratory Research 2010, 11:58

\section{Submit your next manuscript to BioMed Central} and take full advantage of:

- Convenient online submission

- Thorough peer review

- No space constraints or color figure charges

- Immediate publication on acceptance

- Inclusion in PubMed, CAS, Scopus and Google Scholar

- Research which is freely available for redistribution

Submit your manuscript at www.biomedcentral.com/submit
C Biomed Central 